\title{
Analysis of Eclectic Style for Reading and Collection Room at Public Library of Banten Province
}

\author{
Hanifia Tis Adevi ${ }^{1 *}{ }^{2}$ a Yuni ${ }^{2}$ Fivanda Fivanda ${ }^{1}$ \\ ${ }^{1}$ Interior Design Study Program, Faculty of Art and Design, Tarumanagara University, Jakarta, Indonesia \\ ${ }^{2}$ Interior Design Study Program, Faculty of Art and Design, Jakarta Institute of Arts, Jakarta, Indonesia \\ *Corresponding author. Email: hanifia.615170119@stu.untar.ac.id
}

\begin{abstract}
Public library has old and boring impression, the implementation of style to interior design on library is expected to attracts visitors to come to the library. Eclectic style is a combination of various style, ideas and theories from different time to bring one unique style forth. Located in developing region, where modern and traditional lives meet, eclectic style is suitable to be implemented for Public Library of Banten Province interior design, by combining classic and contemporary style. The author analysed the application of eclectic style for reading and collection room at Public Library at Banten Province to find out how far the implementation of the combination between classic style and contemporary style for reading and collection room at Public Library of Banten Province, this room can be said as the "face" of the whole design in the building besides lobby. Most part of finishing use wood pattern HPL, less decoration in monochrome colors, as well as classic simple look but upto-date radiating an even feminine and masculine elegance image. It can be seen that the dominance of the principles and characters of eclectic style has been applied by adjusting the transition from classic and contemporary style.
\end{abstract}

Keywords: Eclectic style, interior design, public library

\section{INTRODUCTION}

Reading should become a culture in society, especially at this modern era. Reading is an activity to search for information in order to enrich insight, enhance knowledge and personal quality. Reading can improve the human resources intelligence to make contribution for advancing a nation or country. One of the attempt to make it come true is the existence of a library.

Libraries are place of collection which contain printed and non-printed materials or information sources on computers that are arranged systematically and beneficial for the users called librarians [1]. Library has to adjust design based on the needs of activity, facility, and technical requirements or regulation as well as apply appropriate image of the library, one of which is the object of this research, Public Library of Banten Province.

Public libraries grow and develop in various kinds of community life, as well as in various cultural diversity. Because of that, the existence of public library is in different conditions. Public library has old and boring impression, known as a place for borrowing books without any further empowerment and it has low visit rate, whereas one of the goals of the public library is as a recreation place to have fun.

The implementation of style to interior design on library is expected to attracts visitors to come to the library because of certain style exudes its characteristics of the library, especially in terms of aesthetics. Furthermore, users get a sense of pleasure that users do not get while in other places beside library.

Based on the profile data and survey carried out by the author, located in developing region, where modern and traditional lives meet, eclectic style is suitable to be implemented for Public Library of Banten Province interior design, by combining classic and contemporary style. Urbanization encourages the growth of small cities into developing regions. Indonesia, which is one of 26 developing countries in East Asia and the Pacific, has some developing regions that influenced by several factors, including economic growth, infrastructure development and demographic changes that allow the region to become competitive [2]. It creates a heterogeneous society due to the migration which then gives birth to new cultures and styles such as acculturation or assimilation [3].

Design application by combining various kind of style usually considered as eclectic style. Eclectic style stem from eclectic architecture which means choosing, combining elements or styles in order to create a new form of style. Eclectic becomes a romantic symbol in architecture due to its various details rich of historical stories [4].

In this study, the author analysed the application of eclectic style for reading and collection room at Public Library at Banten Province to find out how far the implementation of the combination between classic style and contemporary style for reading and collection room at Public Library of 
Banten Province and find out whether it is implemented properly.

Main room of the library of Banten Province is the reading and collection room, this room can be said as the "face" of the whole design in the building besides lobby. Appointed so, because this room contains various book collection, making the room as the most important factor where many users spend time doing activity.

\section{METHODS}

This study uses a qualitative descriptive method. Data collection techniques are the most strategic steps in research, because the main purpose of research is to get data [5]. In qualitative research, collecting data is carried out in natural settings (natural conditions), primary data sources, and more data collection techniques in observation, interviews, and documentation [5]. In this research, the researcher used 2 techniques, observation and documentation.

Observation is a systematic research and record of the elements that appear on the object of research [6]. The author observed on the interior design that the author has created in order to fulfill the requirements of undergraduate final assignment. This analysis was carried out on January 2012.

The scope of the research is the style adjusted on the interior design for Reading Room and General Collection of Regional Libraries in Banten Province based on personal sources.

\section{FINDINGS AND DISCUSSIONS}

Eclectic style is a combination of various style, ideas and theories from different time to bring one unique style forth [7]. The design of the library, applying eclectic style which combines classic and contemporary style with slight of elegant and relaxing traditional style that still looks modern. Nowadays, most societies no longer focus on functions as they do in modern times. Lifestyles and socialites that are increasingly developing create designs that emphasize style and prestige. They want a classic, but not stick on using complicated classic settings. Therefore, this eclectic style, a transition between two style applied as a switchover from classic (traditional) to contemporary (recent).

Eclectic style took off on the end of $19^{\text {th }}$ century up until early of $20^{\text {th }}$ century, when home design became a wealth symbol and show its owner prosperity [8]. Architects, at that moment, wanted to create new style that has never been seen before [8]. By mixing and combining existing styles, with inspirations and freedom of expression, giving birth to eclectic style that has its own identity.

Although, the eclectic style is a style that comes from combining styles through different times, it doesn't look messy since the unification of various styles cannot be done carelessly and should have a focal point.

Contemporary style is a style of design that is influenced by the latest trend. A typical style of furniture design in traditional designs combined with modern style of furniture design become characteristic of the contemporary style. Neutral colors that convey warmth is one of the basic elements of this style. Contemporary style has a characteristic to always demand changes along with the times [9].

Contemporary architecture is a particular style of architecture in its era which reflects the freedom that displays something different and is a new brand or combination of several other architectural styles [10]. Charles Jenks introduced a theory that there are various kinds of designing methods to develop and apply architecture called contemporary architecture, this theory is the basis of contemporary architecture. This theory depends on many factors that influence the period of a particular architectural style [11]. The characteristics of contemporary architecture according to Francisco Asencio, are the expression of the building is subjective, contrast to the surrounding environment and simple shape but give strong impression [12].

Classic style is an interior design from Romanian and Grecian style based on perfect composition, balance, and harmonization. Classic architecture began to develop in Europe, from Grecian times to the Renaissance. Therefore, at the end of classical era many of the buildings keep reusing the same beauty of classical elements, whether combined or applied it entirety. It sometimes referred as Neo-Classics such as Neo-Gothic which often being used due to its beauty and splendor concepts, especially for monumental buildings [13].

At the end of the classical era, there was a surfeit with the forms, concepts and norms of classical architecture, which had ruled the world of architecture for thousands of years, for example the Renaissance when Romanian elements and Grecian elements were still fancied. From historical point of view, the repetition of forms or it can be said that there were not too many choices and mixtures, and were still bound to classical principles, in architectural developments often referred as the Neo-Classical or Post-Renaissance era [14].

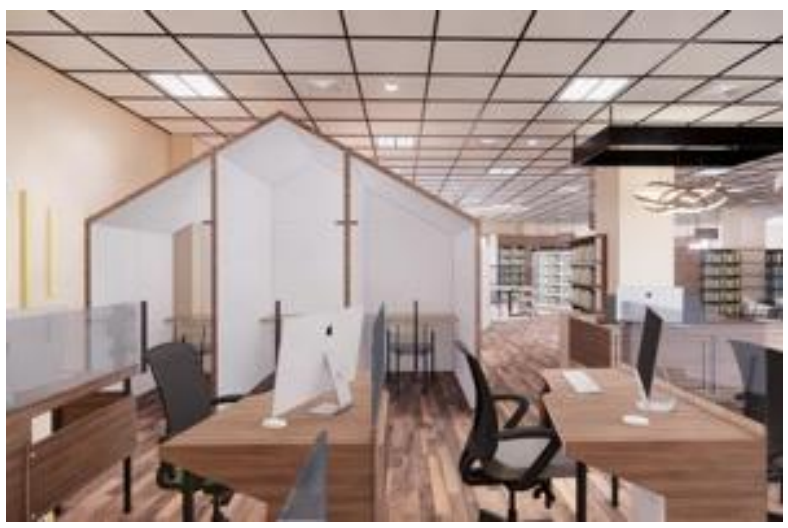

Figure 1 Interior design of private reading area and multimedia area public library of Banten Province (Hanifia Tis Adevi, 2020) 
As can be seen in Figure 1, the multimedia area, which is the area of personal computer and private reading space with house-shaped partitions, displays a simple hip look but still exudes a warm atmosphere from the coloring which is dominated by brown, with gold stripe as wall decoration and metallic materials for tables and chairs leg, radiating a bit of elegant elements.

The house-shaped partition does not represent a certain style, both classic and contemporary facilities, only as a private reading area, which between the librarians has their own space with a triangular roof so that it is not too simple. The application of eclectic style for the library is a transition style that has "gender neutral" as an identity, combination masculine and feminine element from room design to create comfortable and relaxing style [8]. Visually, the eclectic style looks simple, minimalist and elegant [8]. The minimum amount of using room decoration and accessories as the basis identity of contemporary style, combined with elegance from classic style, is one of the identity of this style in order to focus on simplicity and technology in design [8].

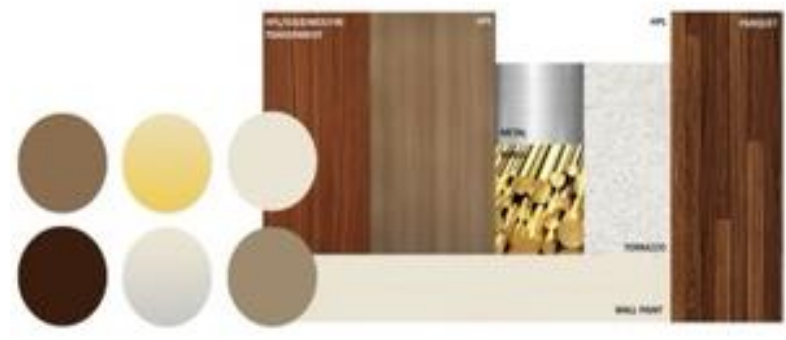

Figure 2 Mateial and color schemes on reading area and public library of Banten Province

(Hanifia Tis Adevi, 2020)

Pallets are usually neutral, smooth and sometimes monochromatic, and accentuation of finishing material such as floor [15]. Neutral colors are color that often appear to balance contrasting colors in nature.

The design of this library, WPC (Wood-Plastic Composite) as the basic material for the bookshelf for finishing, uses wood-motif HPL (High Pressure Laminate) with dark brown color and white HPL to balance it. Indeed, the coloring is dominantly brown (both light and dark), beige. White, with gold accents on certain areas.

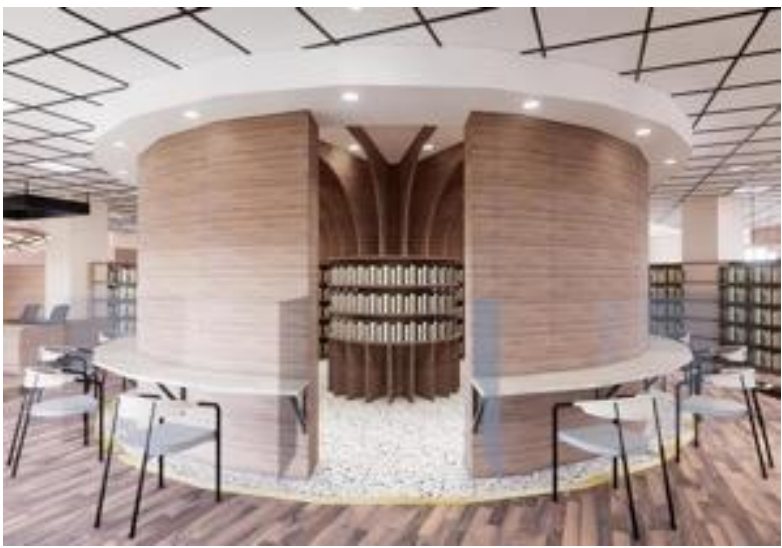

Figure 3 Interior design of round reading area and public library of Banten Province

(Hanifia Tis Adevi, 2020)

From figure 3 , it can be seen that the reading area in the middle section of the library has minimal decoration with monochromic coloring and accentuation on the floor, which is a mixed of terrazzo with parquet that is insulated by brass plint. Other accentuation on the floor is the colors of ceramic which is the combination of black and gold that formed an arrow as a guide to direct the walking circulation in the library. The middle-area bookshelf, forms a circle with a rotating grid on the lower and upper part of it, does not show the character of a certain style with a simple and contemporary design.

The use of wood for finishing is usually warm colored but can be colorful based on the natural surface to the varnish which has a high cluster level. The choice of fabric for coating can be varied based on the material that is obsolete resistant to soft luxurious fabric. The balances mixture on several textures is commonly used in this style.

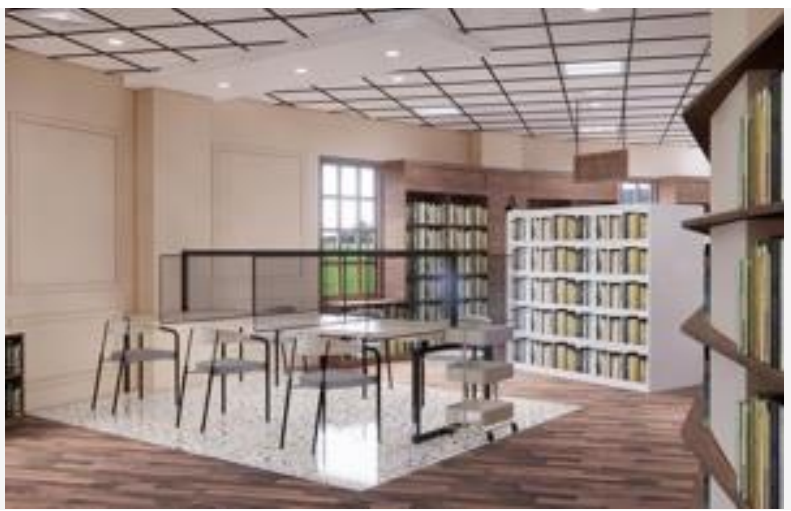

Figure 4 Interior design of reading area and book shelves in collection room public library of Banten Province (Hanifia Tis Adevi, 2020)

As can be seen on Figure 4 above, wood materials as finishing look dominant on the wall shelves with a natural surface and shiny surface table in reading area. This area also has minimum amount of room decoration and accessories. Simple classic appearance but still up-to-date shown on the molding wall treatment and the border of top 
of the wall book shelf and the direction tag that hangs on the ceiling.

The use of cool daylight lighting does not give a warm impression to the atmosphere, which indeed prioritizes the needs of users (librarians) to feel comfortable when reading in the room. There is a classic style armature lamp on part of wall treatment which can be seen in the figure 5 below.

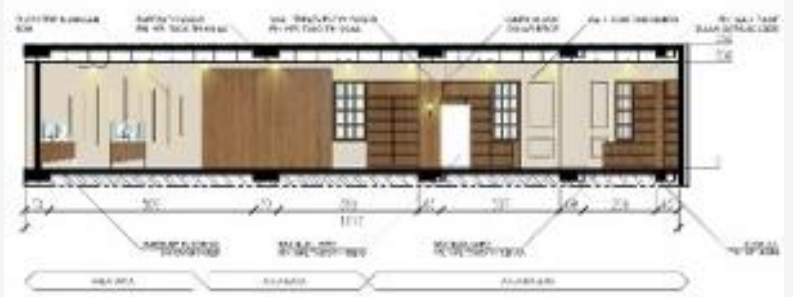

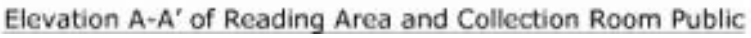
Figure 5 Elevation A-A' of reading area and collection room public library of Banten Province

(Hanifia Tis Adevi, 2020)

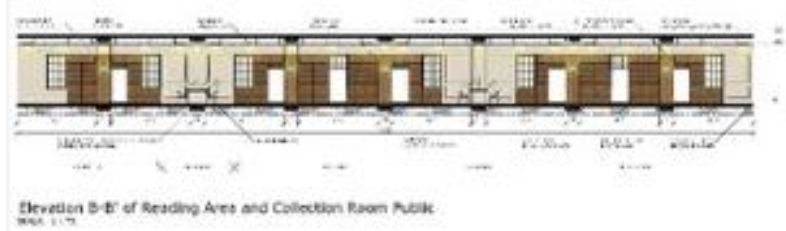

Figure 6 Elevation B-B' of reading area and collection room public library of Banten Province

(Hanifia Tis Adevi, 2020)

The application of the classic style is barely perceptible on this design because there are not many principles or characters from the classic style in this space, and the use of borders and molding from the classic style itself has simplified the shape, the dominance atmosphere of the contemporary design is more perceptible.

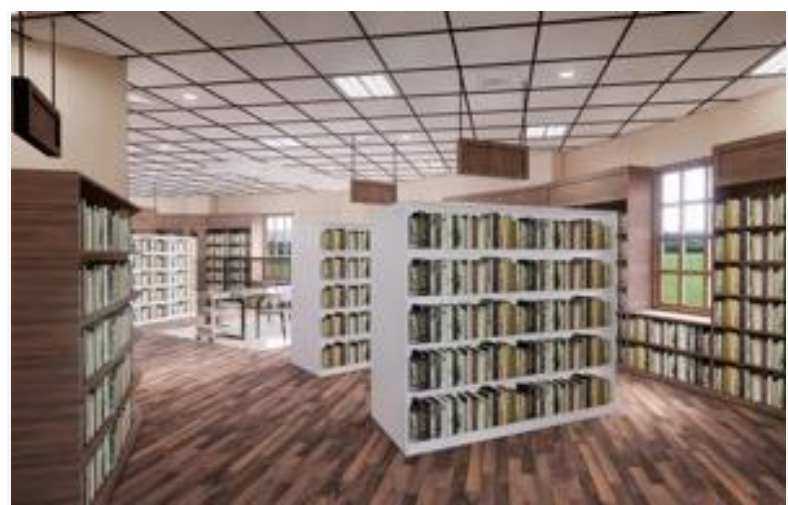

Figure 7 Interior design of book shelves in reading area and collection room public library of Banten Province (Hanifia Tis Adevi, 2020)

The ceiling design by using a grid ceiling with acoustic panels and drop ceiling does not show the character of both contemporary or classic style, it only gives a simple minimalist impression.
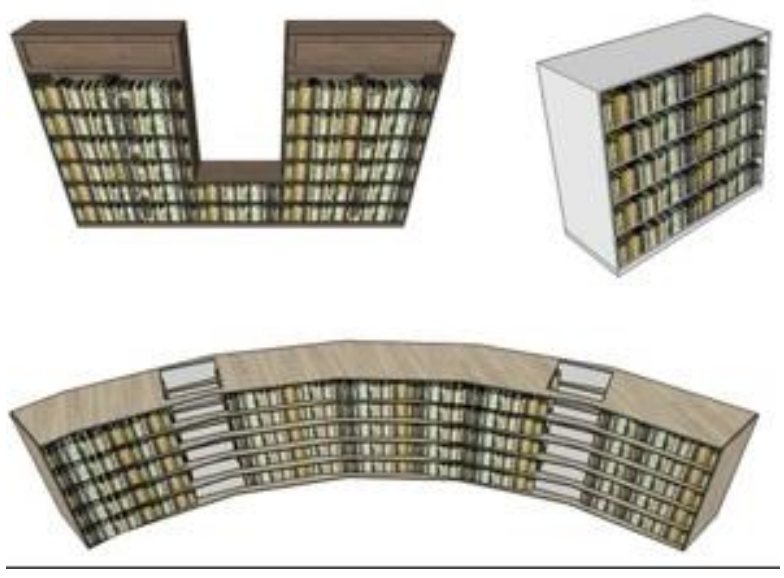

Figure 8 Bookshelf for interior design of reading area and collection room public library of Banten Province (Hanifia Tis Adevi, 2020)

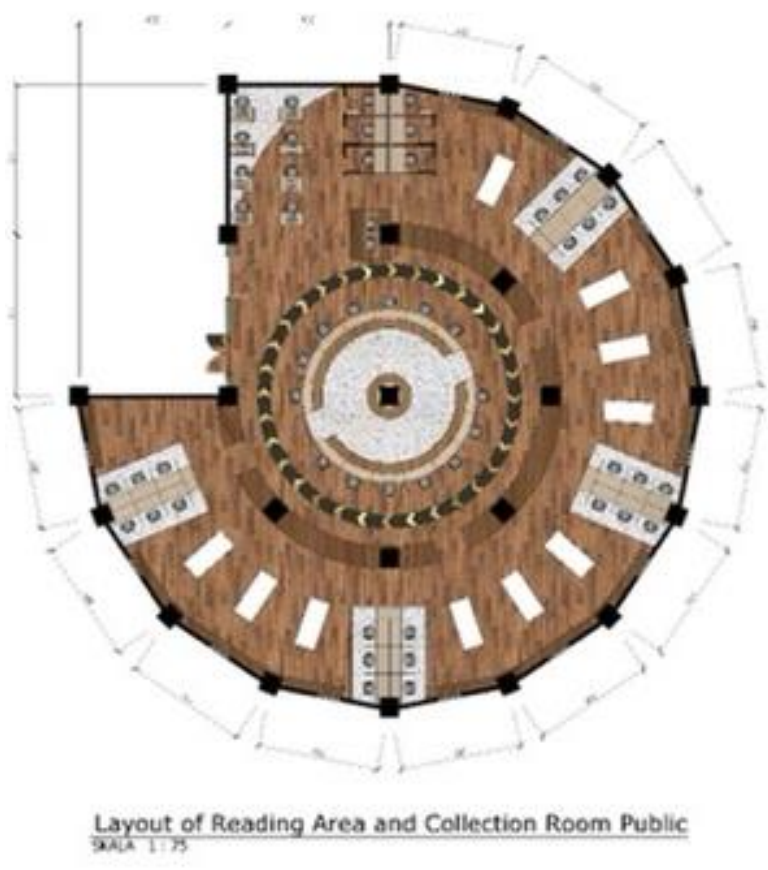

Figure 9 Layout of interior design of reading area and collection room public library of Banten Province

(Hanifia Tis Adevi, 2020)

Most of the bookshelves are designed to focus only on its function, it can be seen from the design which is shaped according to the layout in a minimalist shape, such as circular shelves and white box shelves. 


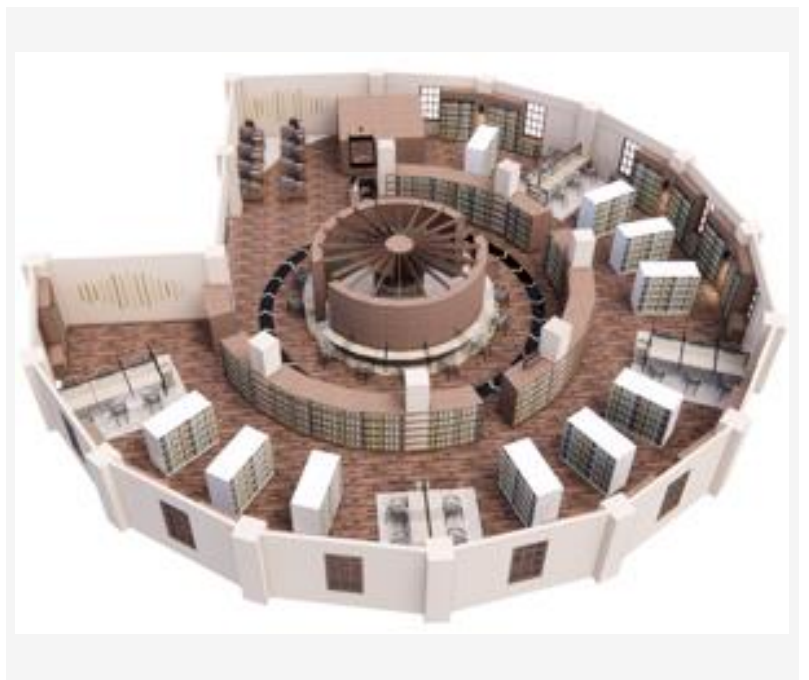

Figure 10 Axonometri of interior design of reading area and collection room public library of Banten Province (Hanifia Tis Adevi, 2020)

From the analysis result of comparison between literature study and new interior design for reading and collection room, it can be seen that the dominance of the principles and characters of eclectic style has been applied, but not very visible because there is still lack of the application of principles and characters of these styles. Overall, the interior design of the library apply simple contemporary style yet still gives warm atmosphere as can be seen on most part of finishing by using wood, less decoration in monochrome colors, as well as classic simple look but contemporary as applied on molding wall treatment and border setting-up on the top of book shelves. By using metal as one of material, radiating an even feminine and masculine elegance image.

\section{CONCLUSIONS}

From the results of comparisons between the literature studies that the author obtained with the new interior design of the Reading Room and Collection Room at Library of Banten Province, it can be seen that the dominance of principles and characters of the eclectic style is applied, but not very visible because there is still lack of the application of principles and characters of these styles. Overall, the interior design of the library apply simple contemporary style yet still gives warm atmosphere as can be seen on most part of finishing by using wood, less decoration in monochrome colors. Aluminium/stainless-steel material and gold color radiating an even feminine and masculine elegance image.

\section{REFERENCES}

[1] S. Basuki, Pengantar Ilmu Perpustakaan, Jakarta: Universitas Terbuka, 2003
[2] United Nations Development Programme. Human Development Reports [Internet]. 2020 [cited 2021 Jan 27]. Available from: http://hdr.undp.org/

[3] S. Soerjono, Sosiologi: Suatu Pengantar, Jakarta: Rajawali Grafindo Persada, 1983

[4] K. Amorani, Ide-Ide Segar Menata Rumah, Jakarta: Gramedia Pustaka Utama, 2009

[5] Sugiyono, Metode Penelitian Kuantitatif, Kualitatif dan R\&D, Bandung: Alfabeta, 2009

[6] E. P. Widoyoko, Teknik Penyusunan Instrumen Penelitian, Yogyakarta: Pustaka Pelajar, 2014

[7] F. K. Tanoko, Dimensi Interior. Penerapan Gaya Eklektik pada Interior Dream of Kahyangan Art Resto Surabaya, Vol. 11, 11-21, 2013

[8] H. B. Alexander. Mengulik Mewahnya Desain Interior Eklektik. 2021 Aug 22. Available from: https://properti.kompas.com/

[9] Y. Hina. Gaya Interior Transisional: Pengaruh Gaya Modern pada Desain Tradisional yang elegan. 2021 Nov 15. Available from: https://interiordesign.id

[10] L. Hilberseimer, Comtemporary Architects 2, Chicago: Paul Theobald and Company, 1964

[11] C. Jencks, K. Kropt, Theories And Manifestoes Of Contemporary Architecture, Cambridge: Academy Press, 1981

[12] A. C. Francisco, The World of Contemporary Architecture XX, Germany: Könemann Verlagsgesellschaft, 2000

[13] H. Harun, Sari Sejarah Filsafat Barat, Jakarta: Kanisius, 1994

[14] Y. E. Wahyuningtyas. Desain Interior Gedung Pertunjukan Seni Tradisional Jawa Di Surakarta (Dengan Pendekatan Eklektik). 2021 Jan 27. Available from: https://core.ac.uk/download/pdf/12347145.pdf

[15] D. Novitasari. Mengenal Gaya Desain Transitional (gaya peralihan) dan Contohnya. $2021 \mathrm{Feb} 3$. Available from: https://hakanaborneosejahtera.co.id 